The Passion [AQ1]

Scale-Portuguese

Version: Reliability,

Validity, and Gender

and Sport Invariance
Perceptual and Motor Skills

$0(0) 1-18$

(C) The Author(s) 2019

Article reuse guidelines: sagepub.com/journals-permissions DOI: $10.1177 / 0031512519849744$ journals.sagepub.com/home/pms

\title{
Luis Cid ${ }^{1,2}(1)$, Anabela Vitorino', Teresa Bento ${ }^{1,2}$, Diogo S. Teixeira ${ }^{3}$, Filipe Rodrigues ${ }^{2,4} \mathbb{D}$, and Diogo Monteiro ${ }^{1,2}$ (1)
}

\begin{abstract}
The aim of this study was to analyze the psychometric properties of the original version of the Passion Scale (14 items, two factors). We tested it within a sample of mixed gender Portuguese athletes from different sports, including adapted sports. In addition to demonstrating reliability, validity, and confirmatory factor analyses of the Passion Scale, we sought to analyze the invariance of this measure between males and females and across six types of sports (soccer, futsal, swimming, surf, bodyboard, and adapted sports). [AQ2]We recruited 1,316 athlete respondents to test this scale from both genders (I, 109 males; 207 females), aged between-14-and-59 years $(M=21.83 ; S D=8.67)$. Our main results revealed weaknesses in the factor model for the original instrument ( 14 items and two factors) leading us to reject the model. However, after adapting the model (eight items and two factors), the psychometric properties of the Passion Scale improved substantially and then exhibited (a) good fit to the data and (b) invariance between gender and across sports. Our new proposed version of the Passion Scale can be used with confidence to analyze the passion athletes feel when practicing their sport.
\end{abstract}

\footnotetext{
'Sport Science School of Rio Maior (ESDRM-IPSantarém), Portugal

${ }^{2}$ Research Centre in Sports, Health and Human Development, Rio Maior, Portugal

${ }^{3}$ Faculty of Physical Education and Sport, Lusófona University, Lisboa, Portugal

${ }^{4}$ University of Beira Interior, Covilhã, Portugal
}

\section{Corresponding Author:}

Luis Cid, Sport Science School of Rio Maior, Polytechnic Institute of Santarém and Research Centre in Sports, Health, and Human Development, Av. Dr. Mário Soares, II 1, 2040-413, Rio Maior, Portugal. Email: luiscid@esdrm.ipsantarem.pt 


\section{Keywords}

passion, sport, adapted sports, factor analysis, multigroup analysis

\section{Introduction}

According to Vallerand et al. (2003), the word "passion" comes from the Latin "passio" (suffer), highlighting a passion-holding perspective that can be anchored in loss of rationality and lack of emotional control. In other words, passion is a strong emotion that tends to control the individual's thinking and behavior. However, in a less controlling perspective, we associate positive feelings with the concept of passion and view it as more rational. In sports, Vallerand and Miquelon (2007) define passion as a strong connection between the individual's affinity for a sport, and the amount of time and energy devoted toward it. In this positive perspective, passion can be conceptualized as the energy source that sustains an athlete's commitment and persistence to any particular sport. Put it in other words, passion is the energy that fuels motivation. In this perspective, the Dualistic Model of Passion (DMP; Vallerand et al., 2003) distinguishes two types of passion: harmonious passion (HP) and obsessive passion (OP), based on how they are internalized (integrated into the individual's identity), with differentiating implications for individual behavior.

HP is associated with autonomous internalization, by which the individual practices sports by free-will, due to a love for the sport rather than to strengthen personal identity. In this kind of passion, the activity does not control the individual; rather the individual practices it without resentment or internal pressure. Therefore, athletes who feel HP to a particular sport tend to better manage time spent on it without feeling conflict between the sport and other daily activities (Vallerand, 2012; Vallerand et al., 2003). Thus, in sports, we can say that an athlete is harmoniously passionate when he or she says, thinks, or feels, "The new things that I discover with this sport allow me to appreciate it even more" (see Item 2 of the Passion Scale [PS] in Table 1).

OP is associated with controlled internalization, in which the individual forces him or herself to engage in sports practice in a search for social acceptance or increased self-esteem, experiencing internalized pressure to do so. Unlike HP, an athlete experiencing OP cannot live without this sport practice and becomes emotionally dependent on it in order to achieve social acceptance and support a personal identity. Therefore, OP athletes have problems managing time spent on sports practice while still performing other activities (Vallerand, 2012; Vallerand et al., 2003). In sports, we can affirm that an athlete has an OP when he or she says, thinks, or feels, "The urge is so strong, I can't help myself from doing this activity" (see Item 9 of the PS in Table 1).

Although DMP was developed over a decade ago, there has been rapidly growing recent research interest in its applicability, particularly in work 
Table I. Descriptive Analysis of the PSp-Initial Model.

\begin{tabular}{|c|c|c|}
\hline & $\begin{array}{l}\text { Minimum- } \\
\text { Maximum }\end{array}$ & $M(S D)$ \\
\hline I) This activity allows me to live a variety of experiences. & $\mathrm{I}-7$ & $6.05(.98)$ \\
\hline $\begin{array}{l}\text { 2) The new things that I discover with this activity allows } \\
\text { me to appreciate it even more. }\end{array}$ & $1-7$ & $5.98(.99)$ \\
\hline 3) This activity allows me to live memorable experiences. & $\mathrm{I}-7$ & $6.21(.98)$ \\
\hline 4) This activity reflects the qualities I like about myself. & $1-7$ & $5.54(1.18)$ \\
\hline 5) This activity is in harmony with the other activities in my life. & $\mathrm{I}-7$ & $5.22(1.28)$ \\
\hline 6) For me it is a passion that I still manage to control. & $\mathrm{I}-7$ & $5.25(1.44)$ \\
\hline 7) I am completely taken with this activity. & $1-7$ & $5.8 I(1.24)$ \\
\hline 8) I cannot live without it. & $1-7$ & $5.25(1.6 I)$ \\
\hline $\begin{array}{l}\text { 9) The urge is so strong, I cannot help myself from } \\
\text { doing this activity. }\end{array}$ & $1-7$ & $5.37(1.50)$ \\
\hline I0) I have difficulty imagining my life without this activity. & $1-7$ & $5.36(1.5 I)$ \\
\hline II) I am emotionally dependent on this activity. & $1-7$ & $4.73(1.65)$ \\
\hline I2) I have a tough time controlling my need to do this activity. & $\mathrm{I}-7$ & $4.36(1.60)$ \\
\hline 13) I have almost an obsessive feeling for this activity. & $\mathrm{I}-7$ & $4.21(1.75)$ \\
\hline 14) My mood depends on me being able to do this activity. & $1-7$ & $4.72(1.70)$ \\
\hline
\end{tabular}

Note. $M=$ mean; $S D=$ standard deviation; $P S p=\mathbf{I}$. [AQ9]

activities (e.g., Egan, Turner, \& Blachman, 2017), the music industry (e.g., Bonneville-Roussy, Lavigne, \& Vallerand, 2010; Bonneville-Roussy \& Vallerand, 2018; Lalande et al., 2015), video gaming (e.g., Bertran \& Chamarro, 2016) and the sports and exercise context (e.g., Lefreniére, Bélanger, Sedikides, \& Vallerand, 2011; Paradis, Cooke, Martin, \& Hall, 2013; Philippe, Vallerand, Andrianarisoa, \& Brunel, 2009; Vallerand et al., 2003, 2006; Vallerand, Mageau, et al., 2008; Verner-Filion, Vallerand, Amiot, \& Mocanu, 2017). However, only recently have there been published studies based on the DMP in the Portuguese sport context (Cid, Ferreira, Sousa, \& Moutão, 2014; Cid \& Louro, 2010; Cid, Silva, Monteiro, Louro, \& Moutão, 2016; Cid, Vitorino, Silva, Ferreira, \& Moutão, 2014; Teixeira \& Cid, 2011). A factor that has slowed DMP's applicability to the Portuguese sport context has been the difficulty assuming that DMP measurement tools are valid and reliable with Portuguese respondents. While the PS, developed by Vallerand et al. (2003), is the most frequently used measurement for studying passion based on DMP theory, there have been concerns regarding the number of PS items for each factor and, consequently, the psychometric properties of the scale. The PS was originally developed in French and later translated into English, with 14 items (seven per each of two factors) selected from an initial pool of 34 items based on factor 
weight from exploratory factor analysis. This two-factor (14 items) instrument was later submitted to a confirmatory factor analysis that required an adjustment to fit the data. Thus, the authors (Vallerand et al., 2006) asserted that some items had "result components" that might have interference-enhancing elements, and they removed these items. Several other studies found similar concerns, since different versions of the scale had been used in separate research applications, including a 6-item version (three items per factor) by Vallerand et al. (2006) and another 8-item version (four items per factor) by Vallerand, Salvy, et al. (2008). These concerns led Vallerand (2010) to revise his own scale, proposing a new 12item version (six items per factor) whose psychometric qualities, when analyzed by Marsh et al. (2013), showed measurement invariance between French and English and between genders. Teixeira and Cid (2011) were the first to translate and validate the original PS (Vallerand et al., 2003) for Portuguese athletes. Through exploratory factor analysis, they identified weaknesses in two items (one item per factor), including low factorial weight and cross-loadings that led these authors to consider eliminating those items. The psychometric properties of this revised Portuguese version of the PS were later reviewed by Cid, Silva, Baptista, Moutão, \& Monteiro (2014) with results that were not entirely conclusive, leading to a rejection of the original measurement model of 14 items and two factors. After eliminating two items in each factor, these authors confirmed substantial improvement that demonstrated adequate psychometric proprieties. Given these inconsistencies in the past literature regarding the PS measurement model and its application to Portuguese respondents, we reexamined the psychometric properties of the original PS (Vallerand et al., 2003), in a population of Portuguese athletes coming from six types of sports, including adapted sports, and we also analyzed the instrument's gender and sport invariance.

\section{Method}

\section{Participants}

A total of 1,316 Portuguese amateur athletes (soccer, futsal, swimming, surf, bodyboard, and adapted sports), from both genders, aged 14 to-59 years $(M=21.83 ; S D=8.67)$ participated in this study. Participants' time of practice in their chosen sports varied from 1 ,to-37 years $(M=8.16 ; S D=5.92)$ and the number of training sessions per week ranged from 1 te-12 $(M=3.77 ; S D=2.13)$. Of these participants, 1,109 were males (age range: $14-59$ years, $M=21.85$; $S D=8.70$; years of practice range: $1-37, M=8.43, S D=6.04$; and number of training sessions per week range: $1-12, M=3.74, S D=2.19)$; 207 were females (age range: $14-53$ years, $M=21.72, S D=8.56$; years of practice range: $1-28$, $M=6.63, S D=4.87$; and weekly training sessions range: $1-11, M=4.28$, $S D=2.65$ ). For cross-validation (i.e., invariance between calibration and 
Table 2. Subsamples Characteristics.

\begin{tabular}{|c|c|c|c|c|c|c|}
\hline \multirow[b]{2}{*}{ Samples } & \multirow[b]{2}{*}{$N$} & \multirow[b]{2}{*}{ Age } & \multicolumn{2}{|c|}{ Gender } & \multirow{2}{*}{$\begin{array}{l}\text { Training } \\
\text { experience } \\
\text { (years) }\end{array}$} & \multirow{2}{*}{$\begin{array}{l}\text { Weekly } \\
\text { training } \\
\text { (sessions) }\end{array}$} \\
\hline & & & Male & Female & & \\
\hline Soccer & 350 & $\begin{array}{c}14-35 \\
(M=|7.6| \\
S D=4.86)\end{array}$ & 358 & - & $\begin{array}{c}I-28 \\
(M=9.08 \\
S D=4.17)\end{array}$ & $\begin{array}{c}I-12 \\
(M=3.28 ; \\
S D=.63 I)\end{array}$ \\
\hline Swimming & 214 & $\begin{array}{c}14-25 \\
(M=15.39 \\
S D=1.90)\end{array}$ & $13 \mid$ & 83 & $\begin{array}{c}1-16 \\
(M=7.10 \\
S D=3.40)\end{array}$ & $\begin{array}{c}4-12 \\
(M=6.86 ; \\
S D=1.5 I)\end{array}$ \\
\hline Surf & 297 & $\begin{array}{c}|5-5| \\
(M=28.64 \\
S D=8.09)\end{array}$ & 246 & 51 & $\begin{array}{c}I-37 \\
(M=9.09 \\
S D=7.7 I)\end{array}$ & $\begin{array}{c}I-10 \\
(M=2.50 ; \\
S D=1.59)\end{array}$ \\
\hline Bodyboard & 169 & $\begin{array}{c}15-45 \\
(M=26.30 \\
S D=7.25)\end{array}$ & $13 \mid$ & 37 & $\begin{array}{c}I-26 \\
(M=9.12 ; \\
S D=6.69)\end{array}$ & $\begin{array}{c}1-10 \\
(M=2.65 ; \\
S D=1.6 I)\end{array}$ \\
\hline Futsal & 135 & $\begin{array}{c}14-18 \\
(M=15.32 \\
S D=1.86)\end{array}$ & 135 & - & $\begin{array}{c}I-10 \\
(M=3.73 \\
S D=2.30)\end{array}$ & $\begin{array}{c}2-5 \\
(M=3.52 ; \\
S D=1.15)\end{array}$ \\
\hline Adapted sports & 143 & $\begin{array}{c}15-59 \\
(M=29.04 \\
S D=10.47)\end{array}$ & 106 & 37 & $\begin{array}{c}I-28 \\
(M=9.12 \\
S D=6.69)\end{array}$ & $\begin{array}{c}I-12 \\
(M=4.52 ; \\
S D=2.7 I)\end{array}$ \\
\hline
\end{tabular}

Note. $N=$ sample size; $M=$ mean; $S D=$ standard deviation.

validation samples), we randomly split data into two samples, each composed of approximately 50\% of the participants, following suggestions by Byrne (2010).

Our calibration sample was composed of 676 athletes (male $=570$, female $=106$; age: $14-59$ years, $M=21.93, S D=8.93$; years of practice range: $1-37, M=7.96, S D=5.84$; and number of weekly training sessions range: $1-12$, $M=3.74, S D=2.19)$. Our validation sample was composed of 640 athletes $($ male $=539$, female $=101$; age range: $14-55$ years, $M=21.72, S D=8.38$; practice years range: $1-30, M=8.37, S D=6.00$ ); and weekly training sessions range: $1-12, M=3.80, S D=2.07)$. Finally, to test measurement invariance, the sample was split into six groups, according to the type of sports practiced. Characteristics of each group (i.e., type of sport practiced) are presented in Table 2.

\section{Instruments}

We used the Portuguese version of the PS (Teixeira \& Cid, 2011), consisting of 14 items on which participants responded on a 7-point Likert-type scale ranging from 1 (Totally disagree) to 7 (Totally agree). Items are grouped into two factors, 
representing HP (e.g., "I am completely taken with this activity"-Item 7 of the PS) and OP (e.g., "I have difficulty imagining my life without this activity"-Item 10 of the PS), underlying DMP.

\section{Data Collection}

Potential participants were individually contacted at their training place or specific location of competition and were questioned as to their willingness to participate voluntarily in this study. We presented participants with a questionnaire alongside a written description of the study's purpose, the names of the authors, collaborators, and partnership identifications, and in which participants were assured of personal confidentiality. To avoid any influence on their sports performance, data were collected $\frac{1}{2}$ hour prior to competition. We obtained the participants' informed consent through their signature on the title page. Time taken to complete the questionnaire was approximately 5,to-10 minutes. Before data collection, we obtained approval from the University for this Research Protocol. Whenever possible, athletes completed the questionnaire independently. However, some adapted sports participants completed the questionnaire with help from coaches, family members, friends, or researchers, and, in these circumstances, we reinforced the imperative of confidentiality and the need to not bias interpretations. Of note, we used several social media (e.g., Facebook) to contact adapted sport athletes when they were engaged in international competitions, or, for athletes with hearing impairments, we used Portuguese Sign Language to assist communications.

\section{Data Analysis}

Confirmatory factor analysis. For confirmatory factor analysis, we followed suggestions made by several authors (Hair, Black, Babin, \& Anderson, 2014; Kline, 2011) and used a ratio of 5:1 for the number of participants for each parameter to be estimated. However, the Mardia's (1970) coefficient indicated a nonnormal multivariate data distribution in all samples under analysis: calibration sample (45.04), validation sample (32.99), male sample (42.32), female sample (30.34), soccer (53.56), futsal (18.65), swimming (8.66), surf (45.77), bodyboard (34.84), and adapted sports (20.92). Therefore, we used bootstrap bollen-stine of 2,000 samples, as suggested by Nevitt and Hancock (2001).

Data analysis was performed according to several authors (Byrne, 2010; Hair et al., 2014; Kline, 2011), such that we used the recommended Maximum Likelihood method, chi-square test $\left(\chi^{2}\right)$, the respective degrees of freedom $(d f)$, and significance level $(p)$. In addition, we used the following adjustment indexes: standardized root mean square residual (SRMR), comparative fit index (CFI), non-normed fit index (NNFI), root mean square error of approximation (RMSEA), and its respective interval of confidence (IC: 90\%). We adopted 
cut-off values (Hair et al., 2014; Marsh, Hau, \& Wen, 2004) for CFI and NNFI $\geq .90$, and for SRMR and RMSEA $\leq .08$. Lastly, we calculated convergent validity (i.e., to test items that converged with the factors) through average variance extracted (AVE), considering values $\mathrm{AVE} \geq .50$ as acceptable. In addition, we reached discriminant validity (i.e., analyze if the factors are sufficiently distinct) by having squared correlation ( $r$ ) of each factor below AVE. To examine internal consistency, we adopted composite reliability (CR) scores, using $\geq .70$ as cut-off values (Hair et al., 2014). The analyses were undertaken using AMOS 23.0

Invariance analysis. Multigroup analysis aims to assess whether the structure of the measurement model is equivalent (invariant) between different participant groups with different characteristics (e.g., male and female). We established the following criteria for models of invariance (Byrne, 2010; Cheung \& Rensvold, 2002; Marsh, 1993): (a) individual model analysis (data must fit each group) and (b) there must be invariance of the following parameters: configural, metric, scalar, and residual. In line with Cheung and Rensvold (2002), configural invariance was met if $\triangle \mathrm{CFI}$ was below .01. For metric invariance, $\triangle$ SRMR had to be less than .030 and $\triangle$ RMSEA less than .015 to support model fit; for scalar, $\triangle$ SRMR had to be less than .010 and $\triangle$ RMSEA less than .015 to indicate measurement invariance (Chen, 2007). According to Marsh (1993), metric invariance is considered to be the minimum criteria for measurement invariance, and the differences between unconstrained model and others (fixed parameters) must be less than $\leq .01$ (Cheung \& Rensvold, 2002). Residual invariance is not indicative of not achieving model invariance, and some authors consider this criterion to be optional since it is too restrictive (Byrne, 2010). Of note, several researchers (e.g., Byrne, 2010) have claimed that analyzing invariance models based on chi-square differences is too restrictive. Therefore, it seems more reasonable to analyze and discuss results based on CFI differences.

\section{Results}

\section{Preliminary and Descriptive Analyses}

As our preliminary data analysis revealed that missing values were less than $0.1 \%$, missing values were imputed using the full information maximum likelihood estimation (Cham, Reshetnyak, Rosenfeld, \& Breitbard, 2017). In addition, we found no outliers (univariate and multivariate). As seen earlier, Table 1 shows a descriptive analysis of participants' responses to all test items. Participants used all levels of response available to them for each of the items, and the mean value per item varied from $4.21(S D=1.75)$ to $6.21(S D=0.98)$, in the calibration sample. 
Perceptual and Motor Skills 0(0)

Table 3. Goodness-of-Fit Indexes of the PSp Measurement Model in All Samples.

\begin{tabular}{lcccccccc}
\hline Models & \multicolumn{1}{c}{$\chi^{2}$} & $d f$ & $p$ & SRMR & NNFI & CFI & RMSEA & $90 \% \mathrm{Cl}$ \\
\hline Initial model (CS) & 735.392 & 76 & $<.001$ & .082 & .830 & .858 & .113 & {$[.106, .121]$} \\
Final model (CS) & 215.774 & 19 & $<.001$ & .080 & .901 & .933 & .124 & {$[.109, .139]$} \\
Final model (VS) & 193.293 & 19 & $<.001$ & .079 & .910 & .939 & .120 & {$[.105, .135]$} \\
Male model & 321.139 & 19 & $<.001$ & .080 & .909 & .939 & .120 & {$[.109, .132]$} \\
Female model & 71.251 & 19 & $<.001$ & .065 & .901 & .933 & .116 & {$[.088, .145]$} \\
Soccer model & 82.461 & 19 & $<.001$ & .070 & .936 & .957 & .097 & {$[.076, .119]$} \\
Swimming model & 61.047 & 19 & $<.001$ & .054 & .920 & .946 & .102 & {$[.074, .131]$} \\
Futsal model & 67.455 & 19 & $<.001$ & .080 & .901 & .919 & .138 & {$[.103, .174]$} \\
Surf model & 195.697 & 19 & $<.001$ & .080 & .897 & .901 & .177 & {$[.155, .200]$} \\
Bodyboard model & 67.635 & 19 & $<.001$ & .079 & .914 & .942 & .177 & {$[.155, .200]$} \\
Adapted sport model & 25.269 & 19 & .152 & .040 & .981 & .987 & .048 & {$[.000, .093]$} \\
\hline
\end{tabular}

Note. $d f=$ degrees of freedom; $S R M R=$ standardized root means square residual; $N N F I=$ non-normed fit index; $\mathrm{CFI}=$ comparative fit index; $\mathrm{RMSEA}=$ root mean square error of approximation; $90 \% \mathrm{Cl}=$ confidence interval; $\mathrm{CS}=$ calibration sample; $\mathrm{VS}=$ validation sample; $\mathrm{PSp}=\mathbf{U}$.

Initial model (I4 items; two factors) and final model (eight items; two factors).

\section{Construct Validity Analysis}

Goodness-of-fit indexes are presented in Table 3. We found that the initial model (14 items and two factors) did not fit the data. Therefore, following recommendations of several prior authors (e.g., Byrne, 2010; Hair et al., 2014), we searched for potential issues through modification and factor weights indices, leading us to eliminate some items: (a) those with factor weights below .50 and (b) those with cross-loadings. The final model was an instrument containing eight items and two factors; and we tested this model on the calibration sample, and, subsequently, on all subsamples according to gender and sports type. As seen in Table 3, the data fit the model for all of these samples, considering the previously mentioned cut-off values. RMSEA scores in all models were higher to the cut-off predefined values adopted in methodology (Byrne, 2010; Hair et al., 2014; Kline, 2011). The only exception was verified in the model regarding adapted sports group $(\mathrm{RMSEA}=.048)$. However, Worthington and Whittaker (2006) indicate that values up to .10 are acceptable.

In Table 4, we present the CR coefficients and the convergent and discriminant validity for each subsample. There were satisfactory values for CR and convergent validity in all models. Similar results were found for discriminant validity for all models.

Regarding measurement invariance, the final model (the scale with two factors and eight items) revealed invariance between the calibration and validation samples, between males and females, and across all the different sports 
Table 4. Internal Consistency, Convergent, and Discriminant Validity.

\begin{tabular}{lccccc}
\hline Models & CR-HP & CR-OP & AVE-HP & AVE-OP & $r^{2}$ \\
\hline Initial model (CS) & .79 & .90 & .37 & .57 & .38 \\
Final model (CS) & .80 & .90 & .51 & .70 & .35 \\
Final model (VS) & .81 & .91 & .52 & .71 & .35 \\
Male model & .84 & .88 & .57 & .64 & .34 \\
Female model & .79 & .89 & .51 & .68 & .41 \\
Soccer model & .87 & .88 & .63 & .64 & .28 \\
Swimming model & .81 & .93 & .52 & .77 & .37 \\
Futsal model & .81 & .92 & .50 & .75 & .44 \\
Surf model & .73 & .89 & .50 & .68 & .29 \\
Bodyboard model & .79 & .93 & .50 & .76 & .44 \\
Adapted sport model & .73 & .90 & .51 & .68 & .29 \\
\hline
\end{tabular}

Note. $\mathrm{CR}=$ composite reliability; $\mathrm{HP}=$ harmonious passion; $\mathrm{OP}=$ obsessive passion; $r^{2}=$ correlation between factors; $\mathrm{AVE}=$ average mean extracted; $\mathrm{CS}=$ calibration sample; $\mathrm{VS}=$ validation sample.

Initial model (I4 items; two factors) and final model (eight items; two factors).

(see Tables 5 and 6). These values indicated: (a) configural invariance (the same number of factors was present in each group), (b) metric invariance (the factors had the same meaning in all samples), (c) scalar invariance (the comparison of latent and observed means was valid between groups), and (d) residual invariance (the comparisons between the observed items were supported).

In terms of local indices, standardized factorial weights ranged from (a) HP of .54 to .79 in the calibration sample, and .77 to .87 in the validation sample and (b) OP of .76 to .86 in the calibration sample, and .77 to .87 in the validation sample. In addition, there was a positive correlation between the two factors of .59 in both samples (see Figure 1).

\section{Discussion}

This study aimed to analyze the psychometric properties of the adapted Portuguese PS (Teixeira \& Cid, 2011). In addition, we tested measurement invariance between genders and the six types of sports (including adapted sports), since previous studies, especially among Portuguese and Spanish participants (e.g., Pedrosa, García-Cueto, Torrado, \& Arce, 2017; Teixeira \& Cid, 2011), have shown inconsistencies. Data from this study demonstrated that the initial model (two factors of seven items each) did not fit the data. After removing three items from each factor, the data exhibited an acceptable fit to the model, leading to an instrument with eight items (four in each of the two factors). In addition, the final model was also found to be invariant between gender samples and across six different sports types. 
Table 5. Measurement Invariance of the Portuguese PS Between Samples, Gender, and Adapted Sports.

\begin{tabular}{|c|c|c|c|c|c|c|c|c|c|c|c|}
\hline Models & $\chi^{2}$ & $d f$ & $\Delta \chi^{2}$ & $\Delta d f$ & $p$ & CFI & $\Delta \mathrm{CFI}$ & SRMR & $\triangle S R M R$ & RMSEA & $\triangle \mathrm{RMSEA}$ \\
\hline \multicolumn{12}{|c|}{ Calibration-Validation } \\
\hline $\mathrm{Cl}$ & 409.066 & 38 & - & - & - & .936 & - & .068 & - & .074 & - \\
\hline MI & $4 I I .440$ & 44 & 2.373 & 6 & .882 & .936 & .000 & .068 & .000 & .073 & .001 \\
\hline $\mathrm{SI}$ & 415.345 & 47 & 6.279 & 9 & .712 & .936 & .000 & .063 & .005 & .068 & .006 \\
\hline RI & 447.508 & 55 & 38.442 & 17 & .002 & .932 & .004 & .059 & .009 & .064 & .010 \\
\hline \multicolumn{12}{|c|}{ Male-Female } \\
\hline $\mathrm{Cl}$ & 392.427 & 38 & - & - & - & .938 & - & .056 & - & .078 & - \\
\hline MI & $4|2.86|$ & 44 & 20.433 & 6 & .002 & .935 & .003 & .054 & .002 & .076 & .002 \\
\hline SI & 441.009 & 47 & 48.582 & 9 & $<.001$ & .931 & .007 & .052 & .004 & .071 & .007 \\
\hline RI & 455.390 & 55 & 62.963 & 17 & $<.001$ & .930 & .008 & .048 & .008 & .069 & .009 \\
\hline \multicolumn{12}{|c|}{ Adapted sports_-Swimming } \\
\hline $\mathrm{Cl}$ & 86.295 & 38 & - & - & - & .961 & - & .067 & - & .062 & - \\
\hline MI & 93.700 & 44 & 7.405 & 6 & .285 & .960 & .001 & .062 & .005 & .062 & .000 \\
\hline $\mathrm{SI}$ & | I7.877 & 47 & 31.582 & 9 & $<.001$ & .953 & .008 & .058 & .009 & .059 & .003 \\
\hline RI & 134.107 & 55 & 47.812 & 17 & $<.001$ & .937 & .024 & .052 & .015 & .058 & .004 \\
\hline \multicolumn{12}{|c|}{ Adapted sports-Surf } \\
\hline $\mathrm{Cl}$ & 220.797 & 38 & - & - & - & .914 & - & .078 & - & .080 & - \\
\hline MI & 226.974 & 44 & 6.177 & 6 & .404 & .914 & .000 & .075 & .003 & .080 & .000 \\
\hline SI & 230.006 & 47 & 9.209 & 9 & .418 & .914 & .000 & .073 & .005 & .075 & .005 \\
\hline RI & 329.231 & 55 & 108.435 & 17 & $<.001$ & .870 & .044 & .071 & .007 & .072 & .008 \\
\hline \multicolumn{12}{|c|}{ Adapted sports-Futsal } \\
\hline $\mathrm{Cl}$ & 92.734 & 38 & - & - & - & .953 & - & .078 & - & .078 & - \\
\hline MI & 94.239 & 44 & $\mathrm{I} .505$ & 6 & .959 & .949 & .004 & .076 & .002 & .078 & .000 \\
\hline SI & I | 3.552 & 47 & 20.818 & 9 & .013 & .948 & .005 & .074 & .007 & .082 & .004 \\
\hline RI & 139.530 & 55 & 46.797 & 17 & $<.001$ & .921 & .032 & .071 & .007 & .069 & .009 \\
\hline \multicolumn{12}{|c|}{ Adapted sports-Soccer } \\
\hline $\mathrm{Cl}$ & 107.707 & 38 & - & - & - & .964 & - & .069 & - & .071 & - \\
\hline MI & $1 \mid 4.810$ & 44 & 7.102 & 6 & .312 & .963 & .001 & .065 & .004 & .069 & .002 \\
\hline SI & 131.206 & 47 & 23.499 & 9 & .005 & .957 & .007 & .061 & .008 & .067 & .004 \\
\hline RI & | 45.327 & 55 & 37.620 & 17 & .003 & .953 & .011 & .059 & .010 & .063 & .008 \\
\hline \multicolumn{12}{|c|}{ Adapted sports-Bodyboard } \\
\hline $\mathrm{Cl}$ & 92.616 & 38 & - & - & - & .958 & - & .068 & - & .074 & - \\
\hline MI & 99.739 & 44 & 7.124 & 6 & .310 & .957 & .001 & .066 & .002 & .072 & .002 \\
\hline SI & 101.400 & 47 & 8.844 & 9 & .457 & .958 & .000 & .064 & .004 & .069 & .005 \\
\hline RI & 204.750 & 55 & 112.135 & 17 & $<.001$ & .885 & .073 & .062 & .006 & .067 & .007 \\
\hline
\end{tabular}

Note. $d f=$ degrees of freedom; $\Delta \chi^{2}=$ differences in $\chi^{2} ; \Delta d f=$ differences in $d f ; C F I=$ comparative fit index; $\Delta \mathrm{CFl}=$ differences in $\mathrm{CFI} ; \mathrm{Cl}=$ configural invariance; $\mathrm{Ml}=$ metric invariance; $\mathrm{Sl}=$ scalar invariance; $\mathrm{RI}=$ residual invariance; $\mathrm{SRMR}=$ standardized root mean square residual; $\triangle \mathrm{SRMR}=$ differences in SRMR; RMSEA = root mean square error of approximation; $\triangle \mathrm{RMSEA}$ = differences in RMSEA. 
Table 6. Measurement Invariance of the Portuguese PS Across Different Sports.

\begin{tabular}{|c|c|c|c|c|c|c|c|c|c|c|c|}
\hline Models & $\chi^{2}$ & $d f$ & $\Delta \chi^{2}$ & $\Delta d f$ & $P$ & CFI & $\Delta \mathrm{CFI}$ & SRMR & $\triangle \mathrm{SRMR}$ & RMSEA & $\triangle \mathrm{RMSEA}$ \\
\hline \multicolumn{12}{|c|}{ Soccer - Swimming } \\
\hline $\mathrm{Cl}$ & 143.522 & 38 & - & - & - & .953 & - & .057 & - & .061 & - \\
\hline MI & 171.003 & 44 & 27.488 & 6 & $<.001$ & .945 & .008 & .055 & .002 & .058 & .003 \\
\hline SI & 222.811 & 47 & 79.289 & 9 & $<.001$ & .943 & .010 & .051 & .006 & .054 & .007 \\
\hline RI & 251.016 & 55 & 107.494 & 17 & $<.001$ & .921 & .032 & .047 & .010 & .051 & .010 \\
\hline \multicolumn{12}{|c|}{ Soccer - Surf } \\
\hline $\mathrm{Cl}$ & 263.093 & 38 & - & - & - & .900 & - & .067 & - & .072 & - \\
\hline MI & 267.331 & 44 & 4.238 & 6 & .645 & .900 & .000 & .067 & .000 & .071 & .001 \\
\hline SI & 305.514 & 47 & 42.421 & 9 & $<.001$ & .894 & .006 & .062 & .005 & .067 & .005 \\
\hline RI & 359.872 & 55 & 94.779 & 17 & $<.001$ & .884 & .016 & .058 & .009 & .062 & .010 \\
\hline \multicolumn{12}{|c|}{ Futsal - Bodyboard } \\
\hline $\mathrm{Cl}$ & I 34.832 & 38 & - & - & - & .932 & - & .078 & - & .056 & - \\
\hline MI & $\mid 46.652$ & 44 & II.820 & 6 & .066 & .928 & .004 & .078 & .000 & .051 & .005 \\
\hline $\mathrm{SI}$ & 182.713 & 47 & 47.881 & 9 & $<.001$ & .925 & .007 & .074 & .004 & .049 & .007 \\
\hline RI & 249.703 & 55 & I | 4.872 & 17 & $<.001$ & .905 & .027 & .071 & .007 & .048 & .008 \\
\hline \multicolumn{12}{|c|}{ Futsal - Swimming } \\
\hline $\mathrm{Cl}$ & 128.552 & 38 & - & - & - & .934 & - & .080 & - & .062 & - \\
\hline MI & $|42.75|$ & 44 & 14.200 & 6 & .027 & .928 & .006 & .071 & .009 & .062 & .000 \\
\hline SI & 193.394 & 47 & 64.843 & 9 & $<.001$ & .925 & .009 & .070 & .010 & .058 & .004 \\
\hline RI & 204.164 & 55 & 75.616 & 17 & $<.001$ & .893 & .041 & .069 & .011 & .057 & .005 \\
\hline \multicolumn{12}{|c|}{ Surf - Bodyboard } \\
\hline $\mathrm{Cl}$ & 262.990 & 38 & - & - & - & .909 & - & .072 & - & .065 & - \\
\hline MI & 276.502 & 44 & $|3.5| \mid$ & 6 & .036 & .906 & .003 & .072 & .000 & .065 & .000 \\
\hline SI & 282.577 & 47 & 19.586 & 9 & .021 & .905 & .004 & .070 & .002 & .059 & .006 \\
\hline RI & 298.940 & 55 & 35.950 & 17 & .005 & .901 & .008 & .066 & .006 & .057 & .008 \\
\hline \multicolumn{12}{|c|}{ Surf - Swimming } \\
\hline $\mathrm{Cl}$ & 256.683 & 38 & - & - & - & .910 & - & .079 & - & .065 & - \\
\hline $\mathrm{MI}$ & 265.884 & 44 & 9.201 & 6 & .163 & .908 & .002 & .078 & .001 & .064 & .001 \\
\hline SI & 307.438 & 47 & 50.755 & 9 & $<.001$ & .900 & .010 & .072 & .007 & .063 & .002 \\
\hline RI & 383.313 & 55 & 126.630 & 17 & $<.001$ & .892 & .018 & .067 & .012 & .057 & .008 \\
\hline \multicolumn{12}{|c|}{ Soccer - Futsal } \\
\hline $\mathrm{Cl}$ & 150.039 & 38 & - & - & - & .946 & - & .072 & - & .066 & - \\
\hline MI & I 54.675 & 44 & 4.635 & 6 & .591 & .946 & .000 & .071 & .001 & .062 & .004 \\
\hline SI & 158.817 & 47 & 8.777 & 9 & .458 & .946 & .000 & .065 & .007 & .061 & .005 \\
\hline RI & 192.290 & 55 & 42.251 & 17 & .001 & .933 & .013 & .064 & .008 & .055 & .011 \\
\hline \multicolumn{12}{|c|}{ Futsal - Surf } \\
\hline $\mathrm{Cl}$ & 278.198 & 38 & - & - & - & .923 & - & .071 & - & .058 & - \\
\hline
\end{tabular}


Table 6. Continued

\begin{tabular}{|c|c|c|c|c|c|c|c|c|c|c|c|}
\hline Models & $\chi^{2}$ & $d f$ & $\Delta \chi^{2}$ & $\Delta d f$ & $p$ & $\mathrm{CFI}$ & $\Delta \mathrm{CFI}$ & SRMR & $\triangle S R M R$ & RMSEA & $\triangle \mathrm{RMSEA}$ \\
\hline MI & 294.118 & 44 & 15.920 & 6 & .014 & .919 & .004 & .069 & .002 & .058 & .000 \\
\hline $\mathrm{SI}$ & 334.972 & 47 & 56.774 & 9 & $<.001$ & .913 & .010 & .065 & .006 & .056 & .002 \\
\hline RI & 445.113 & 55 & 166.915 & 17 & $<.001$ & .874 & .049 & .060 & .011 & .051 & .007 \\
\hline \multicolumn{12}{|c|}{ Soccer - Bodyboard } \\
\hline $\mathrm{Cl}$ & | 49.887 & 38 & - & - & - & .951 & - & .073 & - & .061 & - \\
\hline MI & 178.040 & 44 & 28.153 & 6 & $<.001$ & .942 & .009 & .071 & .002 & .059 & .002 \\
\hline $\mathrm{SI}$ & 219.750 & 47 & 69.863 & 9 & $<.001$ & .941 & .010 & .070 & .003 & .058 & .003 \\
\hline RI & 319.555 & 55 & 169.669 & 17 & $<.001$ & .885 & .066 & .069 & .004 & .052 & .009 \\
\hline \multicolumn{12}{|c|}{ Bodyboard - Swimming } \\
\hline $\mathrm{Cl}$ & 128.426 & 38 & - & - & - & .944 & - & .078 & - & .079 & - \\
\hline MI & | 44.787 & 44 & $|6.36|$ & 6 & .012 & .937 & .007 & .075 & .003 & .078 & .001 \\
\hline SI & 160.798 & 47 & 32.372 & 9 & $<.001$ & .935 & .009 & .072 & .006 & .077 & .002 \\
\hline RI & 254.501 & 55 & 126.075 & 17 & .001 & .929 & .015 & .067 & .011 & .074 & .005 \\
\hline
\end{tabular}

Note. $d f=$ degrees of freedom; $\Delta \chi^{2}=$ differences in $\chi^{2} ; \Delta d f=$ differences in $d f ; C F I=$ comparative fit index; $\Delta \mathrm{CFl}=$ differences in $\mathrm{CFI} ; \mathrm{Cl}=$ configural invariance; $\mathrm{Ml}=$ metric invariance; $\mathrm{Sl}=$ scalar invariance; $\mathrm{RI}=$ residual invariance; SRMR = standardized root mean square residual; $\triangle \mathrm{SRMR}$ = differences in SRMR; RMSEA = root mean square error of approximation; $\triangle \mathrm{RMSEA}$ = differences in RMSEA.

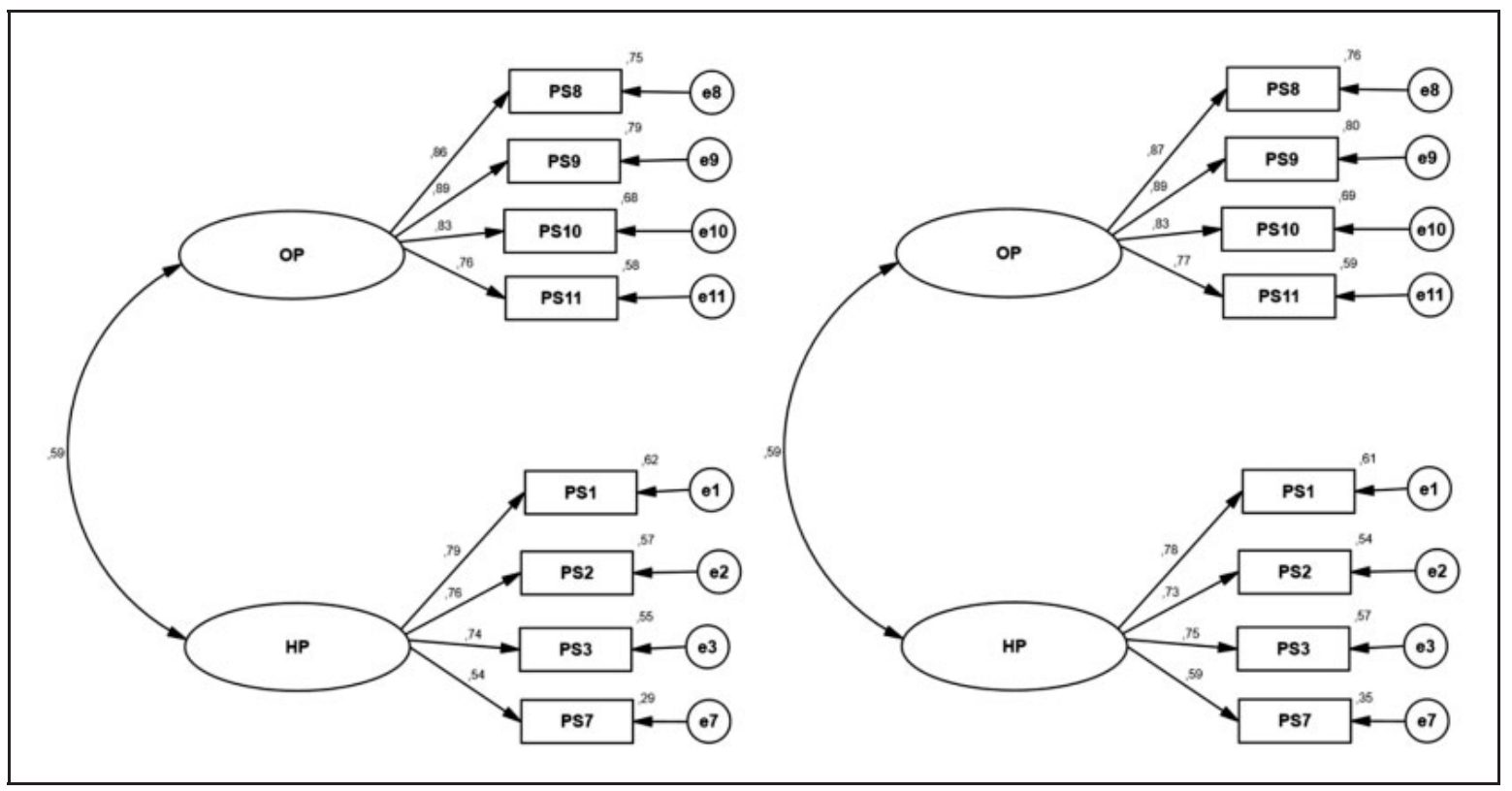

Figure I. Standardized parameter (covariance's between factors, factor weights, and error of measurement) from calibration (left) and validation (right), all statistically significant in its respective factor (eight items and two factors).

$\mathrm{OP}=$ obsessive passion; $\mathrm{HP}=$ harmonious passion. 


\section{Construct Validity Analysis}

Past analyses of the PS have led researchers to recommend shorter versions of the scale. For example, Vallerand et al. (2006) suggested a test with only six items, Vallerand, Salvy, et al. (2008) formed a scale with eight items, and Cid, Silva, et al. (2014) recommended a test for Portuguese athletes with eight items. Later, Vallerand (2010) proposed a new version of the PS that employed 12 items in two factors with some slight modifications that were later analyzed (in French and English versions) by Marsh et al. (2013), and a later validated to Spanish by Chamarro et al. (2015). However, these versions of the PS only showed an acceptable data fit after correlating measurement errors between two items in the HP factor and two items in the OP factor. This could mean that the shorter versions are a better option for analyzing these factors.

Interestingly, these results revealed that individuals from several different countries value both types of passion, a fact that seems to be demonstrated by the moderate and high means of all of the items (e.g., Vallerand et al., 2006; Vallerand, Salvy, et al., 2008). This may be due, in part, to the positive correlation between both types of passion, not only in this study $(r=.59)$ but also in all studies validating this scale (Chamarro et al., 2015; Cid, Silva, et al., 2014; Marsh et al., 2013; Pedrosa et al., 2017; Vallerand et al., 2003).

Regarding the psychometric properties of the initial model in this study (i.e., the scale with 14 items in two factors), our data did not show an acceptable fit to the model, corroborating weaknesses in the full version. Therefore, it was necessary to analyze a shorter version, considering that it is not necessary to have so many items (observations) for each factor (latent construct). For example, Hair et al. (2014) recommended the use of only four items. This practice is common in scale validation when the models are complex and show construct validity problems associated with larger numbers of items (Cid, Moutão, Leitão, \& Alves, 2012; Monteiro et al., 2018). This strategy has been used successfully by the PS author himself in several studies (Vallerand \& Miquelon, 2007; Vallerand et al., 2006; Vallerand, Salvy, et al., 2008). These studies indicated that the shorter versions might be a better alternative than the full version, and our results support this conclusion.

Item elimination should be guided by the assurance of maintaining the integrity of the theoretical model (Henson \& Roberts, 2006). Therefore, after analyzing the local adjustment indices and the modification indices, we eliminated three items from each factor (Items 12,13, and 14 of the OP factor and Items 4, 5, and 6 of the HP factor), following two main principles: (a) We retained only factor weights $>.50$ and (b) we retained only items that did not correlate significantly with other items from the same factor (no cross-loadings). Thus, we ensured that no doubts were raised from a semantic point of view and no eliminated items would bias interpretation.

Following Hair et al. (2014) recommendations, our results support the use of the shorter and final version (two factors with eight items each), as items then 
better reflect the latent construct that the scale is meant to measure. In addition, this shorter version exhibited good fit in accordance with such other important components as: (a) cross-validation (i.e., there were no differences between the calibration and validation samples), (b) convergent validity (i.e., all factors had scores above cut-off values), and (c) discriminant validity (i.e., both factors were distinct and measured different types of passion). CR values were acceptable ( $\geq .70)$, meaning that the scale measures both factors consistently and reproducibly (Hair et al., 2014) just as did the original scale (Vallerand et al., 2003).

\section{Measurement Invariance}

Our measurement invariance analyses supported the use of this revised scale for participants of both genders and all six types of sports examined (i.e., soccer, futsal, swimming, surf, bodyboard, and adapted sports) according to Marsh et al. (2013). The theoretical constructs underlying DMP were conceptualized in the same way in among all of these participant subsamples. Following several authors' recommendations regarding invariance analysis (Byrne, 2010; Chen, 2007; Cheung \& Rensvold, 2002), we can confirm that (a) the proposed theoretical structure is equivalent in all samples examined, (b) factor weights corresponded in all samples, and (c) test users can compare results between males and females and between athletes engaged in different types of sports. In addition, there is a linguistic equivalence and applicability of this revised PS (Vallerand et al., 2003) across other countries in the sport context.

\section{Study Limitations}

Our results support the applicability of the Portuguese version of the PS for sport athletes, but there are some limitations to this research. First, the present scale was applied among Portuguese athletes, and generalization to other countries remains speculative until further research. Second, this study was cross-sectional in its design, meaning that it is not clear how the instrument's psychometric properties might change through athletes' development until longitudinal research has been conducted. Thus, this research was based on a strong theoretical model, and future interventions can help in assessing HP and OP in athletes and test for time invariance. Third, although we found solid evidence of a difference between Passion constructs of HP and OP, future studies should associate scores on this instrument with other motivational or emotional variables. For example, Zhao, St-Louis, and Vallerand (2015) in a study with Chinese participants demonstrated that HP was significantly positively associated with positive emotions and significantly negatively associated with negative emotions, while $\mathrm{OP}$ was significantly positively associated with both positive and negative emotions. Finally, this analysis exhibited an adjusted fit for measurement invariance between samples involving gender and six different types of 
sports, and forthcoming studies should examine invariance between other group characteristics (e.g., countries, collectivism and individualism sports, amateur, and professional athletes).

\section{Conclusion}

The results of this study showed that is it not advisable to use all 14 items split between two factors as in the original version of the PS in Portuguese athletes, as this model exhibited construct validity problems. However, this research proposed an alternative shorter version of the PS with eight items in two factors in examining athlete's passion across gender and across different types of sports, including adapted sports. This shorter version exhibited an acceptable fit to the data and invariance between these subsamples. However, we agree with Barrett (2007) that more studies are needed, involving tests of invariance not only across other types of sports but also across another groups (e.g., age) and for transcultural validation (e.g., Portugal, Spain, and others Latino American countries). Importantly, future studies should also further explore the PS model proposed by Vallerand (2010) to better understand its broader meaning.

\section{Declaration of Conflicting Interests}

The author(s) declared no potential conflicts of interest with respect to the research, authorship, and/or publication of this article.

\section{Funding}

The author(s) disclosed receipt of the following financial support for the research, authorship, and/or publication of this article: This work is supported by national funding through the Portuguese Foundation for Science and Technology, I.P., under project UID/DTP/04045/2019.

\section{ORCID iD}

Luis Cid (D) https://orcid.org/0000-0001-8156-3291

Filipe Rodrigues (D) https://orcid.org/0000-0003-1327-8872

Diogo Monteiro (D) https://orcid.org/0000-0002-7179-6814

\section{References}

Barrett, P. (2007). Structural equation modelling: Adjudging model fit. Personality and Individual Differences, 42, 815-824. doi:10.1016/j.paid.2006.09.018

Bertran, E., \& Chamarro, A. (2016). Videogamers of league of legends: The role of passion in abusive use and in performance. Adicciones, 28(1), 28-34.

Bonneville-Roussy, A., Lavigne, G. L., \& Vallerand, R. J. (2010). When passion leads to excellence: The case of musicians. Psychology of Music, 39(1), 123-138. doi:10.1177/ 0305735609352441

Byrne, B. (2010). Structural equation modeling with AMOS. Basic concepts, applications, and programming (2nd ed.). New York, NY: Taylor \& Francis Group, LLC. 
Cham, H., Reshetnyak, E., Rosenfeld, B., \& Breitbard, W. (2017). Full information maximum likelihood estimation for latent variable interactions with incomplete indicators. Multivariate Behavior Research, 52(1), 12-30. doi:10.1080/00273171.2016. 1245600

Chamarro, A., Penelo, A., Fornieles, A., Ursula, O., Vallerand, R., \& Fernández-Castro, J. (2015). Psychometric properties of the Spanish version of the Passion Scale. Psicothema, 27(4), 402-409. doi:10.7334/psicothema2015.80

Chen, F. (2007). Sensitivity of goodness of fit indexes to lack of measurement invariance. Structural Equation Modeling, 14(3), 464-504. doi:10.1080/10705510701301834

Cheung, G., \& Rensvold, R. (2002). Evaluating goodness-of-fit indexes for testing measurement invariance. Structural Equation Modelling: A Multidisciplinary Journal, 9(2), 233-255. doi:10.1207/S15328007SEM0902_5

Cid, L., Ferreira, J., Sousa, C., \& Moutão, J. (2014). Paixão, Motivação, Performance e Bem-Estar Subjetivo dos Praticantes de Surf. In L. Carvalhinho (Ed.), Desporto de Natureza e Turismo Ativo - Contextos e Desenvolvimento (pp. 195-213). Rio Maior, Portugal: Edições ESDRM-IPSantarém [AQ3].

Cid, L., \& Louro, H. (2010). Praticar Natação é uma Paixão ou um Sacrifício? Estudo da Relação entre o Tipo de Paixão que o Atleta sente pela Modalidade e a sua Orientação Motivacional. Revista Iberoamerica de Psicología del Ejercicio y el Deporte, 5(1), 99-114 [AQ4].

Cid, L., Moutão, J., Leitão, J., \& Alves, J. (2012). Translation and validation of the exercise adaptation of the Perceived Motivational Climate Sport Questionnaire, Motriz. Revista de Educação Física, 18(4), 708-720. doi:10.1590/S198065742012000400009

Cid, L., Silva, A., Monteiro, D., Louro, H., \& Moutão, J. (2016). Paixão, Motivação e Rendimento dos Atletas de Natação. Revista Iberoamericana de Psicología del Ejercicio y el Deporte, 11(1), 53-58.

Cid, L., Silva, M., Baptista, P., Moutão, J., \& Monteiro, D. (2014). Paixão pela Prática Desportiva: Análise das Qualidades Psicométricas da Versão Portuguesa da Passion Scale (PSp). In Congresso de Ciências do Desporto, Exercício e Saúde (p. 30). Vila Real, Portugal: Universidade de Trás-os-Montes e Alto Douro [AQ5].

Cid, L., Vitorino, A., Silva, C., Ferreira, J., \& Moutão, J. (2014). Paixão, Motivação e Felicidade dos Praticantes de Surf. In T. Batista et al. (Eds.), IX Congresso Iberoamericano de Psicologia e $2^{\circ}$ Congresso da Ordem dos Psicólogos Portugueses (pp. 1083-1096). Lisboa, Portugal: Ordem dos Psicólogos Portugueses [AQ6].

Egan, R., Turner, M., \& Blackman, D. (2017). Leadership and employee work passion: Propositions for future empirical investigations. Human Resource Development Review, 16(4), 394-424. doi:10.1177/1534484317724634

Hair, J., Black, W., Babin, B., \& Anderson, R. (2014). Multivariate data analysis (7th ed.). Hoboken, NJ: Pearson Educational, Inc.

Henson, R., \& Roberts, J. (2006). Use of exploratory factor analysis in published research. common errors and some comment on improved practice. Educational and Psychological Measurement, 66(3), 393-416. doi:10.1177/0013164405282485

Kline, R. (2011). Principles and practice of structural equation modeling (3rd ed.). New York, NY: The Guilford Press. 
Lefreniére, M., Bélanger, J., Sedikides, C., \& Vallerand, R. (2011). Self-esteem and passion for activities. Personality and Individual Differences, 51(4), 541-544. doi:10.1016/ j.paid.2011.04.017

Mardia, K. (1970). Measures of multivariate skewness and kurtosis. Biometrika, 57(3), 519-530. doi:10.1093/biomet/57.3.519

Marsh, H. (1993). The multidimensional structure of physical fitness: Invariance over gender and age. Research Quarterly for Exercise and Sport, 64(3), 256-273. doi:10.1080/02701367.1993.10608810

Marsh, H., Hau, K., \& Wen, Z. (2004). In search of golden rules: Comment on hypothesis testing approaches to setting cutoff values for fit indexes and dangers in overgeneralizing $\mathrm{Hu}$ and Bentler's (1999) findings. Structural Equation Modeling, 11(3), 320-341. doi:10.1207/s15328007sem1103_2

Marsh, H. W., Vallerand, R. J., Lafrenière, M.-A. K., Parker, P., Morin, A. J. S., Carbonneau, N., ... Paquet, Y. (2013). Passion: Does one scale fit all? Construct validity of two-factor passion scale and psychometric invariance over different activities and languages. Psychological Assessment, 25(3), 796-809. doi:10.1037/a0032573

Monteiro, D., Borrego, C., Silva, C., Moutão, J., Marinho, D., \& Cid, L. (2018). Motivational Climate Sport Youth Scale. Measurement invariance across gender and five different sports. Journal of Human Kinetics, 61, 249-261. doi:10.15.15/ hukin-2017-0124

Nevitt, J., \& Hancock, G. (2001). Performance of bootstrapping approaches to model test statistics and parameter standard error estimation in structural equation modeling. Structural Equation Modeling, 8(3), 353-377. doi:10.1207/S15328007SEM0803_2

Paradis, K., Cooke, L., Martin, L., \& Hall, G. (2013). Too much of a good thing? Examining the relationship between passion for exercise and exercise dependence. Psychology of Sport and Exercise, 14(4), 493-500. doi:10.1016/ j.psychsport.2013.02.003

Pedrosa, I., García-Cueto, E., Torrado, J., \& Arce, C. (2017). Adaptación Española de la Escala de Pasión al Ámbito Deportivo. Revista Iberoamericana de Diagnóstico y Evaluación, 1(43), 165-176. doi:10.21865/RIDEP43_165 [AQ7]

Philippe, F., Vallerand, R. J., Andrianarisoa, J., \& Brunel, P. (2009). Passion in referees: Examining their affective and cognitive experiences in sport situations. Journal of Sport \& Exercise Psychology, 31(1), 77-96. doi:10.1123/jsep.31.1.77

Teixeira, P., \& Cid, L. (2011). Tradução e validação preliminar da versão portuguesa da Passion Scale (PS) para o contexto do desporto. In A. Ferreira et al. (Eds.), Actas do VIII Congresso Iberoamericano de Avaliação/Evaluación Psicológica e XV Conferência Internacional de Avaliação Psicológica: Formas e Contextos (pp. 1369-1375). Lisboa, Portugal: Sociedade Portuguesa de Psicologia [AQ8].

Vallerand, R. (2012). The dualistic model of passion in sport and exercise. In G. Roberts \& D. Treasure (Eds.), Advances in motivation in sport and exercise (3rd ed., pp. 169-206). Champaign, IL: Human Kinetics.

Vallerand, R., Blanchard, C., Mageau, G., Koestner, R., Ratelle, C., Léonard, M., ... Marsolais, J. (2003). Les Passions de l'Âme: On Obsessive and Harmonious Passion. Journal of Personality and Social Psychology, 85(4), 756-767. doi:10.1037/ 0022-3514.85.4.756 
Vallerand, R., Mageau, G., Elliot, A., Dumais, A., Demers, M.-A., \& Rousseau, F. (2008). Passion and performance attainment in sport. Psychology of Sport and Exercise, 9(3), 373-392. doi:10.1016/j.psychsport.2007.05.003

Vallerand, R., \& Miquelon, P. (2007). Passion for sport in athletes. In S. Jowett \& D. Lavalle (Eds.), Social psychology in sport (pp. 249-263). Champaign, IL: Human Kinetics.

Vallerand, R., Rousseau, F., Grouzet, F., Dumais, A., Grenier, S., \& Blanchard, C. (2006). Passion in sport: A look at determinants and affective experiences. Journal of Sport \& Exercise Psychology, 28(4), 454-478. doi:10.1123/jsep.28.4.454

Vallerand, R., Salvy, S., Mageau, G., Elliot, A., Denis, P., Grouzet, F., \& Blanchard, C. (2008). On the role of passion in performance. Journal of Personality, 75(3), 505-533. doi:10.1111/j.1467-6494.2007.00447.x

Vallerand, R. J. (2010). On passion for life activities: The dualistic model of passion. In M. P. Zanna (Ed.), Advances in experimental social psychology (Vol. 42, pp. 97-193). New York, NY: New York Academic Press.

Verner-Filion, J., Vallerand, R. J., Amiot, C. E., \& Mocanu, I. (2017). The two roads from passion to sport performance and psychological well-being: The mediating role of need satisfaction, deliberate practice, and achievement goals. Psychology of Sport \& Exercise, 30, 19-29. doi:10.1016/j.psychsport.2017.01.009

Worthington, R., \& Whittaker, T. (2006). Scale development research. A content analysis and recommendations for best practices. The Counseling Psychologist, 34(6), 806-838. doi: $10.1177 / 0011000006288127$

Zhao, Y., St-Louis, A., \& Vallerand, R. (2015). On the validation of the Passion Scale in Chinese. Psychology of Well-Being, 5(3), 1-12. doi:10.1186/s13612-015-0031-1

\section{Author Biographies \\ Luis Cid II [AQ10]}

\section{Anabela Vitorino}

Teresa Bento

Diogo S. Teixeira

Filipe Rodrigues

Diogo Monteiro 